\title{
Ornamental Ichthyofaunal Diversity of North Guwahati, Assam, India
}

\author{
Shamim Rahman ${ }^{1}$,Sumanjit Kakati ${ }^{2}$,Jitendra Kumar Choudhury ${ }^{3}$,Prabhat \\ Chandra Sarma ${ }^{4}$, Ellora Barua ${ }^{*}$ and Amalesh Dutta ${ }^{5}$ \\ 1,2,3,4.* Institutional Biotech Hub, Department of Zoology, North Gauhati College, India \\ ${ }^{5}$ Department of Zoology, Gauhati University, India
}

\begin{abstract}
In this current study, ornamental fish diversity of North Guwahati region is explored, contemplating entrepreneurship potential to provide livelihood opportunities to the fringe villagers with a view to facilitate fish biodiversity conservation. Mostly lentic water ecosystems are considered for ornamental fish diversity documentation. A total of 28 fish species with 17 families and 24 genera have been categorized into different status under potential ornamental fish. Out of these, 16 species are grouped having 'excellent ornamental value', while 9 other species fall under 'high ornamental fish' status based on established guidelines. Besides, economic importance as food value of these fish species have been complemented along with the ornamental importance to look into the actual people's preference of the fishes in this region. Scientific exploration of ornamental ichthyofauna of North Guwahati region, wetlands of which are facing threat and being deteriorated due to rapid urbanization of Guwahati city and industrial establishment, would involve fringe villagers in conservation practices because of the entrepreneurship aspects of ornamental fishes all over the globe.
\end{abstract}

Key words: Assam, North Guwahati, Ornamental fish, Wetland

\section{Introduction}

North Guwahati is an ecologically important region with rich floral and faunal diversity. The southern part of the same city of Guwahati is one of the fastest growing cities of the country, while the northern part bears a rural ambience. But with the expansion of the city and the establishment of industries, it has been transformed to an industrial city within a decade [1]. The region holds vast diversity of ichthyofauna in the good number of wetlands. The core Guwahati city, the southern bank with the state capital of Assam, the gateway to Northeast India and the hub for trade, commerce and travel, is forwarding toward north bank with the rapid urbanization. As a result, the wetlands of this area are shrinking leading to habitat loss for many flora and fauna. Many of the wetlands have been vanished from the good face of the earth. Thus, it is the need of the hour to document the floral and faunal diversity of this region to hammer out scientific conservation and management strategies.

There are many tribal and non tribal villages in and around North Guwahati region. Most of the fringe villagers are with low income rate. The importance of this study lies in the fact that it would indulge public participation in conservation of fish diversity and fish habitats from extinction. The entrepreneurship option of ornamental fish would attract attention of common mass to contribute in the conservation of fish diversity of this region.

Ornamental fishes, also known as aquarium fish, are characterized by attractive colouration and shape. The graceful movement is also one of the prime characteristic features of ornamental fishes. Early fish keeping record dates back to 4000 years past. Egyptian wall paintings of 1400 B.C. reveals decorative mood behind fish keeping at that time. Most justifiable credit goes to Chinese for true gold fish domestication [2]. P.H.Goss is known to apply the terminology 'aquarium' in the year 1855 [3]. Trade and culture of ornamental fishes from tropical freshwater systems have become one of the important components of current day aquaculture practices. Ornamental fish farming, comprising breeding of indigenous fish species, has now been included in cottage industry of India [4]. Along with direct economic benefits from the ornamental fish industry including fish and aquarium tank and fabrication material, it also supports secondary ecological and economic practices such as conservation of aquatic habitat, aquatic plants and animals. In India, this industry is far below from the actual potential. Assam, which is part of Northeast biodiversity hotspot of India, is blessed with numerous wetlands [5]. Socio-climatic condition of Northeast India is favourable for fish farming. Expansion of ornamental trade in this region would generate employment opportunities for local people and pave a way for earning foreign exchanges for the country. Understanding the potential, Northeastern states need to grab the opportunity of ornamental fish farming in large scale [4]. Wetlands or beels of Assam hold huge diversity of fishes having ornamental importance. In this study, mostly ornamental fishes of the wetlands of North Guwahati region are recorded. Many of the floodplain areas or beels of North Guwwhati are connected to the Brahmaputra River 
flowing nearby. This contributes more to the fish diversity of lentic water ecosystems of North Guwahati region with the occasional addition of lotic water fishes.

\section{The study area}

The area of the North Guwahati region is about 52 square kilometer. It is situated around the coordinate of $26^{\circ} 12^{\prime} 28^{\prime \prime}$ North and $91^{\circ} 44^{\prime} 10^{\prime \prime}$ East and it is at about 168 feet high from the sea level. The whole region is uneven with a number of water bodies and hilly terrains. The climatic condition of this region is sub tropical with hot weather in summer and cold in winter. The annual average recorded temperature is $28.67^{\circ} \mathrm{C}$, annual average rainfall is $159.7 \mathrm{~cm}$, and annual average humidity is $81.01 \%$. This region is situated along the river Brahmaputra and connected with the river by the drainage such as 'Nowakhalijaan', 'Ghorajaan', 'Siligurijaan' etc. [1].

\section{Materials and Method}

Fishes were collected from several specific sampling stations (Table 1) and adjoining areas during the period of June, 2012 to January, 2014. Vast wetland areas of this region are explored and lentic water fishes are considered in this study. Due to seasonal river connections, lotic water fishes are also reported in the stagnant water bodies.

Table 1: Sampling sites with the coordinates

\begin{tabular}{|l|l|l|}
\hline Sl. No. & \multicolumn{1}{|c|}{ Sampling station } & \multicolumn{1}{c|}{ Coordinate } \\
\hline 1 & North Guahati College campus and the adjoining areas & $26^{\circ} 12^{\prime} 8^{\prime \prime}$ North $91^{\circ} 42^{\prime} 56^{\prime \prime}$ East \\
\hline 2 & Ghorajaan wetland and the adjoining areas & $26^{\circ} 12^{\prime} 17^{\prime \prime}$ North $91^{\circ} 41^{\prime} 46^{\prime \prime}$ East \\
\hline 3 & Lathia Bagicha and the adjoining areas & $26^{\circ} 10^{\prime} 59^{\prime \prime}$ North $91^{\circ} 41^{\prime} 45^{\prime \prime}$ East \\
\hline 4 & Siligurijaan and the adjoining areas & $26^{\circ} 14^{\prime} 51^{\prime \prime}$ North $91^{\circ} 45^{\prime} 22^{\prime \prime}$ East \\
\hline 5 & Kating pathar and the adjoining areas & $26^{\circ} 12^{\prime} 22^{\prime \prime}$ North $91^{\circ} 41^{\prime} 26^{\prime \prime}$ East \\
\hline 6 & Bhetamukh and the adjoining areas & $26^{\circ} 13^{\prime} 35^{\prime \prime}$ North $91^{\circ} 42^{\prime} 44^{\prime \prime}$ East \\
\hline 7 & Bhetarjaan and the adjoining areas & $26^{\circ} 13^{\prime} 21^{\prime \prime}$ North $91^{\circ} 42^{\prime} 39^{\prime \prime}$ East \\
\hline 8 & Woutaalpool and the adjoining areas & $26^{\circ} 13^{\prime} 2^{\prime \prime}$ North $91^{\circ} 42^{\prime} 31^{\prime \prime}$ East \\
\hline
\end{tabular}

Fishes were collected mainly from commercial fishing and small scale fishing for domestic consumption by local tribes. Commercial fisherman uses casting nets, while in other case, bamboo made 'Jakoi' and 'Chepa' are used by tribal people for fishing. Collected samples were photographed before their identification and preservation. Fishes were sorted into groups and Identification was carried out following taxonomic keys [6], [7], [8], [9]. Most of identified samples were preserved in either 4-7\% formalin solution or in $95 \%$ ethanol depending upon need of further downstream processing of the samples for molecular characterization in further studies. Fishes, those could be brought to laboratory in living condition, reared in aquarium for behavioural observation with special attention to tolerance level of the fish in aquarium and uptake of artificial food.

From the ichthyofaunal collection of North Guwahati region, ornamental fishes were clustered with general considerations of the group such as body colouration, morphology, tolerance to aquarium environment etc. These were further discriminated as 'excellent' and 'high' potential ornamental fishes based on criteria employed by National Bureau of Fish Genetic Resources, Lucknow such as on 'size, shape and colouration pattern', 'survivelity and acclimatization in the aquarium', 'acceptance of synthetic food', 'compatibility with other species' and 'market demand' [4]. Ornamental consideration of fish is almost nil in this area. Food value of these fishes has also been evaluated to complement the economic importance in totality. Availability of species during sampling process at different period and people's preference, through questionnaire, to species as ornamental and for future fish farming were also considered to attain ground reality of potential of species and background information for priority based need for conservation and management of species in peril. Food value and availability were indicated through three sequential categories; 'high', 'moderate' and 'low' and 'abundant', 'moderate' and 'low' respectively (Table 2). Conservation status of all the species were crosschecked with CAMP (1998) report [10] and current IUCN (2013) conservation status [11].

\section{Results}

A total of 28 fish species had been categorized as ornamental fishes having potential for entrepreneurship source for the fringe villagers in and around the region. These 28 fish species comprises of 17 families (fig. 1) and 24 genera. 
Ornamental Ichthyofaunal Diversity of North Guwahati, Assam, India

Table 2: List of ornamental fishes with ornamental potential*, food value, occurrence and conservation status

\begin{tabular}{|c|c|c|c|c|c|}
\hline SL No. & Scientific Name & $\begin{array}{c}\text { Ornamental } \\
\text { potential }\end{array}$ & Food Value & Occurrence & $\begin{array}{c}\text { Conservation status } \\
\text { CAMP,1998/IUCN } \\
2013\end{array}$ \\
\hline 1 & Notopterus notopterus (Pallas, 1769) & Excellent & High & Low & LRnt/LC \\
\hline 2 & Laubuca laubuca (Hamilton, 1822) & High & Moderate & Low & LRIc/LC \\
\hline 3 & Danio rerio (Hamilton, 1822) & Excellent & Moderate & Low & LRnt/LC \\
\hline 4 & Amblypharyngodon mola (Hamilton,1822) & Excellent & High & Abundant & LRlc/LC \\
\hline 5 & Puntius sophore (Hamilton, 1822) & High & High & Abundant & LRnt/LC \\
\hline 6 & Puntius ticto (Hamilton, 1822) & High & High & Moderate & LRnt/LC \\
\hline 7 & Esomus danricus (Rao \& Sharma, 1972) & Excellent & Moderate & Low & LRlc/LC \\
\hline 8 & Botia Dario(Hamilton, 1822$)$ & Excellent & Moderate & Low & NE/LC \\
\hline 9 & Lepidocephalichthys guntea (Hamilton, 1822) & Excellent & Moderate & Low & NE/LC \\
\hline 10 & Mystus vittatus (Bloch,1794) & High & High & Low & VU/LC \\
\hline 11 & Rhinomugil corsula (Hamilton, 1822) & High & Low & Low & VU/LC \\
\hline 12 & Xenentodon cancila (Hamilton, 1822) & High & Moderate & Low & LRnt/LC \\
\hline 13 & Macrognathus pancalus (Hamilton, 1822) & Excellent & High & Moderate & LRnt/LC \\
\hline 14 & Macrognathus aral (Bloch \& Schneider, 1801) & Excellent & High & Moderate & LRnt/LC \\
\hline 15 & Chanda nama (Hamilton, 1822) & Excellent & Moderate & Moderate & $\mathrm{NE} / \mathrm{LC}$ \\
\hline 16 & Parambassis ranga (Hamilton, 1822) & Excellent & Moderate & Moderate & NE/LC \\
\hline 17 & Badis badis (Hamilton, 1822) & Excellent & Low & Low & $\mathrm{NE} / \mathrm{LC}$ \\
\hline 18 & Nandus nandus (Hamilton, 1822) & High & High & Moderate & LRnt/LC \\
\hline 19 & Glossogobius giuris (Hamilton, 1822) & High & High & Low & LRnt/LC \\
\hline 20 & Anabas testudineus (Bloch,1792) & High & High & Moderate & VU/DD \\
\hline 21 & Trichogaster fasciata (Bloch \& Schneider, 1801) & Excellent & Moderate & Abundant & LRnt/LC \\
\hline 22 & Channa panctatus (Bloch, 1793) & Excellent & High & Abundant & LRnt/NE \\
\hline 23 & Channa striata (Bloch, 1793) & Excellent & High & Moderate & LRlc/LC \\
\hline 24 & Channa marulius (Hamilton,1822) & Excellent & High & Low & LRnt/LC \\
\hline 25 & Tetraodon cutcutia (Hamilton, 1822) & Excellent & Low & Low & LRnt/LC \\
\hline 26 & Monopterus cuchia (Hamilton, 1822) & -------------- & High & Moderate & LRnt/LC \\
\hline 27 & Clarius magur (Linnaeus,1758) & --------------- & Moderate & Low & VU/NE \\
\hline 28 & Heteropneustes fossilis (Bloch,1794) & 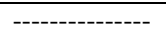 & Moderate & Moderate & VU/LC \\
\hline
\end{tabular}

(*Ornamental potential based on NBFGR-Atlas [4]. EN- Endangered; VU-Vulnerable; LRnt-Lower risk near threatened; LRlc- Lower risk least concern, DD-Data deficient, LC-Least Concern, NT-Near threatened ; NENot evaluated)

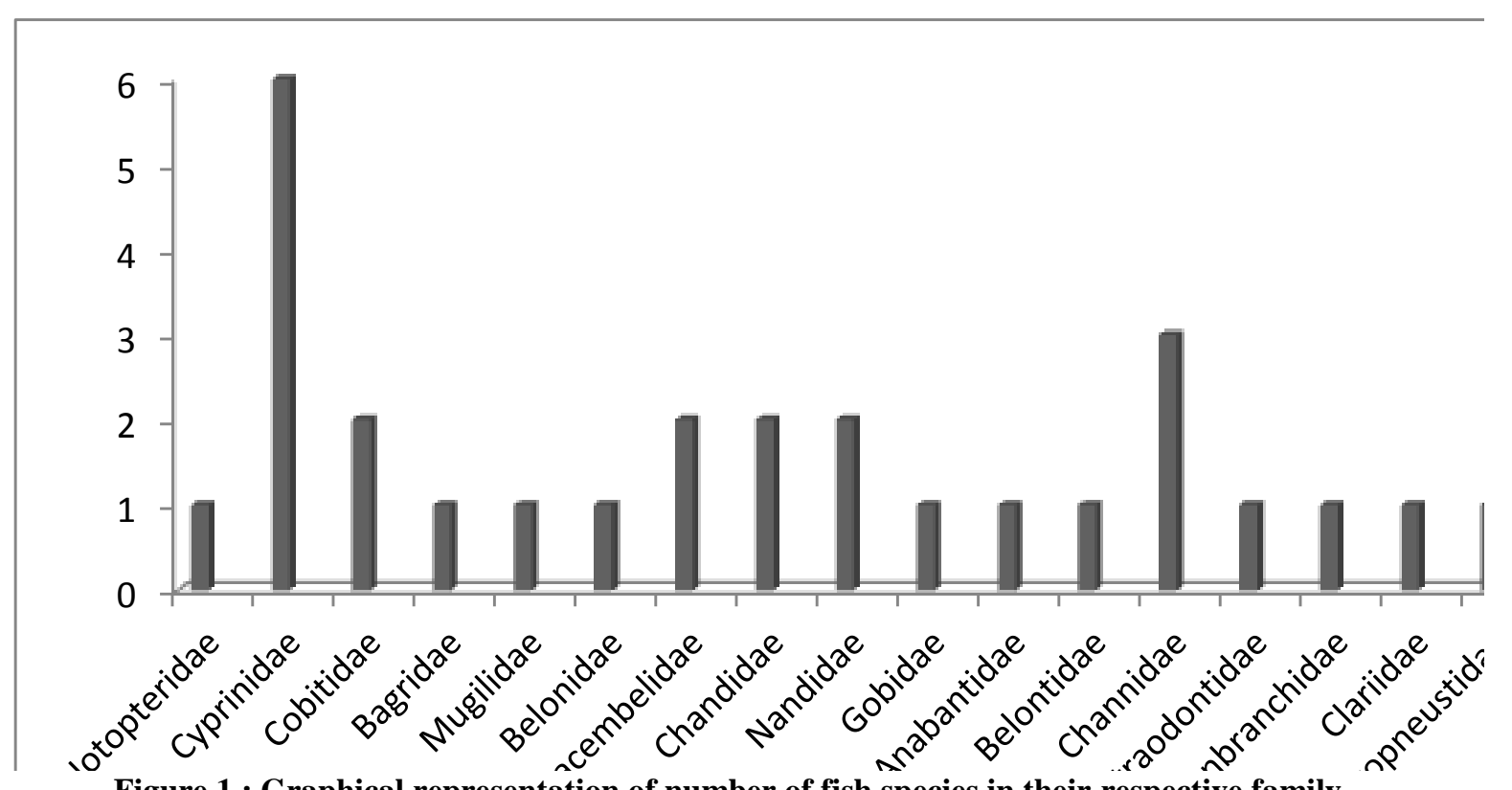

Figure 1 : Graphical representation of number of fish species in their respective family

16 fish species, out of 28 , had been found with excellent ornamental value in this study while 9 species were clustered as high potential ornamental fish. Although Monopterus cuchia is not included in the atlas [4], it has been regarded as an ornamental fish of Assam [12], [13]. Similarly Clarius magur [12], [13] and Heteropneustes fossilis [13] have got ornamental fish status of Assam. In consonance with the routine food practice of the state, almost every fish species bear food value. However, one 'excellent' ornamental fish species Badis badis rarely has any food value in this region and thus often discarded as weed fish in commercial fishing practices and die inside mud kept unattended on bank of water bodies after sorting of food fish. Similarly, Rhinomugil corsula 
occasionally gets into the food fish list along with miscellaneous fish species and Tetraodon cutcutia, in general, not consumed by fringe villagers knowing its possession of toxin. Although all three Channa species are regarded as excellent ornamental fish, people's preference to Channa species is low here from ornamental point of view. Channa striata and Channa marulius are not the people's choice because of the size the fishes attain at maturity and the difficulties associated with their management in aquarium. Channa panctatus, although does not attain much larger body size, fails to attract attention as ornamental fish in practical. However, all three Channa species bear high economic value as food fish and many a time compatible with Indian major carps.

\section{Conclusion}

Fishes are the cheapest source of animal protein for human being in this region, like other parts of the state of Assam. A huge number of indigenous fish species bear enormous potential as ornamental value. Scientific exploration of fish and other biological groups in this region is rare. Ornamental fish diversity study has brought forward documentation of fish species having ornamental importance present at North Guwahati. Moreover, ornamental fishes are categorised into different status such as 'excellent' and 'high' considering established guidelines and people's preference through interview. The findings from the study advocate the need of immediate conservation and management strategy for the species Badis badis as occurrence and preference are low, in contrast of the highly excellent ornamental potential. The study reveals that other than food value, economic importance such as ornamental fish farming gets little importance in this region. Glossogobius guries also needs immediate attention as both its occurrence and preference are low. Botia dario, regarded as an excellent ornamental fish, also highly preferred among villagers for future fish farming but low in occurrence throughout the year. No exceptions with Laubuca laubuca, Esomus danricus, Danio rerio, Lepidocephalichthys guntea, Mystus vittatus, Xenentodon cancila, being low in occurrence and high in potential and preference. Questionnaire among villagers suggests need of promotion of Amblypharyngodon mola as this species does not hold much ornamental importance among people in spite its excellent ornamental importance and high availability in this area. The habitats of fish fauna are rapidly shrinking with the expansion of the city. Immediate rehabilitation of Badis badis and Rhinomugil corsula is utmost important from the vanishing wetlands. Rearing and breeding of Badis badis, Puntius spp., Botia spp., Danio spp., are the needful actions to be taken without further delay before their extinction from this region along with the wetlands. Promotion of indigenous fish species as ornamental and their culture would draw attention of fringe people knowing the entrepreneurship scope. Government initiative for providing training on ornamental fish culture and aquarium preparation would be some fruitful approach for this purpose. This would indirectly contribute the protection and conservation fish diversity and fish habitats of North Guwahati which is rich in fish diversity present in the good numbers of wetlands.

\section{Acknowledgement}

This study is a part of research work of 'Institutional Biotech Hub' of North Gauhati College, established through Department of Biotechnology, Government of India support under 'Biotech Hub Scheme'. We sincerely acknowledge DBT, Govt. of India for financial aid to carry out the project.

\section{References}

[1] P. K. kalita, North Guwahati and its industrial environment, Souvenir: Golden jubille celebration committee, North Gauhati College, 2013, 107-109, 166.

[2] S. A. Fossa, Mam-made fish: Domesticated fish and their place in the aquatic trade and hobby, OFI journal, 44. 2004, 1, 3-4, 6-10, 12-16.

[3] I. Petrovicky, The illustrated guide to tropical aquarium fishes (Chancellor Press, London, 1993).

[4] S.P.Biswas, J.N.Das, U.K.Sarkar and W.S.Lakra, Ornamental fishes of North East India: An Atlas (National Bureau of Fish Genetic Resoures, Lucknow, 2007).

[5] A. G. Jhingran and, V. Pathak, Ecologyand management of beels in Assam- A casestudy of three beels :Compendium Proc. Workshop onDevelopment of Beel Fisheries in Assam.Assam Agricultural University, Khanapara, Guwahati. 1987, 16-36.

[6] W.Vishwanath, W.S.Lakra and U.K.Sarkar. Fishes of North East India (National Bureau of Fish Genetic Resoures, Lucknow, 2007).

[7] Shagufta, Fish Anatomy (APH Publishing Corporation, New Delhi, 2012).

[8] P.K.Talwar and A.G.Jhingran, Inland fishes of India and adjacent countries vol. 1 and 2 (Oxford and IBH Publishing Co. Pvt. Ltd., 1991).

[9] K.C.Jayaram, The freshwater fishes of Indian region (Narendra Publishing House, Delhi, 2010).

[10] Freshwater fishes of India in S.Molur and S.Walker (Ed), Conservation Assessment and Management Plan (C.A.M.P) report (Insia: Zoo outreach organisation/ CBSG, 1998)

[11] URL: www.iucnredlist.org

[12] O.K.Dutta, Ornamental ichthyofauna of Assam, in A.G.Ponniah and U.K.Sarkar (Ed.), Fish biodiversity of North East India (Lucknow: National Bureau of Fish Genetic Resources, 2000) 115-117.

[13] M.K.Das and S.Bordoloi, Diversity of ornamental fishes in the river island Majuli, Assam, Global journal of bio-science and biotechnology, 1(1), 2012, 81-84. 